\title{
Glacial lake change risk and management on the Chinese Nyainqentanglha in the past 40 years
}

\author{
Wang Shijin \\ State Key Laboratory of Cryospheric Sciences, Cold and Arid Regions Environmental and Engineering Research \\ Institute, Chinese Academy of Sciences, Lanzhou, Gansu, 730000, China \\ *Correspondence Address: Donggang West Road 320, Lanzhou, Gansu, China 730000. \\ Email: xiaohanjin@126.com. \\ Fax: +86 0931 4967336; Tel.: +8609314967339.
}

\begin{abstract}
The paper analyzed synthetically spatial distribution and evolution status of moraine-dammed lakes in the Nyainqentanglha Mountain, revealed risk degree of county-based potential dangerous glacial lakes (PDGLs) outburst floods disaster by combining PDGLs outburst hazard, regional exposure, vulnerability of exposed elements and adaptation capability and using the Analytic Hierarchy Process and Weighted Comprehensive Method. The results indicate that 132 moraine-dammed lakes $(>0.02$ $\mathrm{km}^{2}$ ) with a total area of $38.235 \mathrm{~km}^{2}$ were detected in the Nyainqentanglha in the $2010 \mathrm{~s}$, the lake number decreased only by $5 \%$, whereas total lake area expanded by $22.72 \%$, in which 54 lakes with a total area of $17.53 \mathrm{~km}^{2}$ are identified as PDGLs and total area increased by $144.31 \%$, higher significantly than $4.06 \%$ of non-PDGLs. The zones at very high and high integrated risk of glacial lakes outburst floods (GLOFs) disaster are concentrated in the eastern Nyainqentanglha, whereas low and very low integrated risk zones are located mainly in the western Nyainqentanglha. On the county scale, Nagque and Nyingchi have the lowest hazard risk, Banbar has the highest hazard and vulnerability risk, Sog and Lhorong have the highest exposure risk. In contrast, Biru and Jiali have the highest vulnerability risk, while Gongbo'gyamda and Damxung have lowest adaptation capacity. The regionalization results for GLOF disaster risk in the study are consistent with the distribution of historical disaster sites across the Nyainqentanglha.
\end{abstract}

KEYWORDS. moraine-dammed lake; potentially dangerous glacial lakes; disaster risks; assessment and regionalization; Nyainqentanglha Mountain

\section{Introduction}

The globally averaged combined land and ocean surface temperature data as calculated by a linear trend, shows a warming of 0.85 [0.65 to 1.06] ${ }^{\circ} \mathrm{C}$, over the period 1880 to 2012. The total increase between the average of the 1850-1900 period and the 2003-2012 period is 0.78 [0.72 to 0.85$]^{\circ} \mathrm{C}$, based on the single longest dataset available (IPCC, 2013). Global warming has led to the rapid retreat of mountain glaciers, the formation of new glacial lakes, the expansion of existing glacial lakes (Yao, 2010) and increased potential for GLOFs (Clague and Evans, 2000; Nayar, 2009; Worni et al., 2012; Wang et al., 2015).

GLOF is low-frequency event, but it often causes enormous loss and damage of life, property and human environment in downstream regions. GLOFs have frequently been reported in the Himalaya, Peruvian Andes (Cordillera Blanca), Chilean Patagonia, Canadian Rockies, Nyainqêntanglha range (Worni et al., 2013; Haeberli and others, 2013; Wang et al., 2015). For 
Nat. Hazards Earth Syst. Sci. Discuss., doi:10.5194/nhess-2016-300, 2016

Manuscript under review for journal Nat. Hazards Earth Syst. Sci.

Published: 27 September 2016

(c) Author(s) 2016. CC-BY 3.0 License.

Natural Hazards

and Earth System

Sciences

Discussions

example, over 21 GLOF disasters have been reported in Peru's Cordillera Blanca, killing nearly 30, 000 people during the past 65 years (Carey, 2005, 2008; Carey et al., 2012). According to past records, at least 16 GLOFs have occurred in Chinese Nyainqêntanglha since 1935 (Wang and Zhang, 2013). The occurrence of recent classic outbursts at a lake of Palong Zangbu (i.e. river), 2007, Cilaco Lake of Nujiang River, 2009 and at Recireco lake of Yigong Zangbu, 2013 in Nyainqêntanglha shows that the threat of GLOFs requires appropriate and continued attention well into the 21 st century, as glacier retreat continues (Wang et al., 2015). Especially, on 5 July 2013, Recireco lake (an area of about $57 \times 10^{4} \mathrm{~m}^{2}$ ) outburst occurred in the eastern Nyainqêntanglha and then formed mudslides. As a result, some persons were missing, numerous buildings were destroyed, and some infrastructures were damaged. The total economic loss was estimated as 200 million RMB. Facts have proved that: the economic losses caused by GLOF are much higher than the project costs to early consolidate moraine dam and release flood waters.

GLOF disasters result from both natural and social factors and their interactions. GLOF risks not only include the hazard of glacial lake outburst, but also involve the vulnerability and adaptation capacity of exposed elements. The hazard of glacial lake outburst can be defined as the product of outburst magnitude and outburst probability (Mckillop and Clague, 2007). However, GLOF impacts, regional exposure, the vulnerability of exposed elements and the adaptation capacity downstream have received less consideration or synthetic and quantitative assessment in previous studies. In fact, glacial lake outbursts can be very difficult and expensive to control, but regional exposure and the vulnerability of exposed elements downstream can be reduced by improving adaptation capacity and risk management level (Wang et al., 2015).

This study analyzed synthetically county-based spatial distribution characteristics and evolution status of moraine-dammed lakes and potential dangerous glacial lakes (PDGLs), identified and analyzed GLOF disaster risk, and established a risk assessment system including glacial lake outburst hazard, regional exposure, the vulnerability of exposed elements and the adaptation capacity downstream. Finally, the study quantified the degree of risk of GLOFs in the study area using GIS technology, the analytic hierarchy process (AHP) and the weighted comprehensive method (WCM). The study is not only of significance for analyzing glacial lake outburst hazard and assessing the exposure and vulnerability of exposed elements in Nyainqentanglha, but also has important theoretical reference to provide a scientific support for prevention and mitigation planning of GLOF disaster, infrastructure construction, industry distribution and village land use planning in GLOF affected areas.

\section{Study area}

Nyainqentanglha range, with the leghth of about $740 \mathrm{~km}$, locates in the border belt between the Indian and Eurasian plate. The highest peak located in the mostwestern part of Nyainqêntanglha with the altitude of $7162 \mathrm{~m}$ (Fig. 1). The study region $\left(90.50^{\circ}-97.80^{\circ} \mathrm{E}\right.$; $29.15^{\circ}-32.20^{\circ} \mathrm{N}$ ) covers an area of $48.82 \mathrm{~km}^{2}$, accounting for $39.74 \%$ of the land area of the Tibet Autonomous Region. It is bordered to the south by Yarlung Zangbo (Brahmaputra River), to the west by Qiongmugang peak (7 $048 \mathrm{~m}$ ) on North of Ma River, to the north by Tanggula Mountain, and to the east by Hengduan Mountain (Fig. 1). Nyainqentanglha developes a large number of modern glaciers and is one of largest glaciation center of the middle and low latitude in the world. The second Glacier Inventory (Liu et al., 2015) shows 
Nat. Hazards Earth Syst. Sci. Discuss., doi:10.5194/nhess-2016-300, 2016

Manuscript under review for journal Nat. Hazards Earth Syst. Sci.

Published: 27 September 2016

(c) Author(s) 2016. CC-BY 3.0 License.

Nyainqêntanglha exists 6860 glaciers with an area of $9559.20 \mathrm{~km}^{2}$ in $2010 \mathrm{~s}$ and the number and area of glaciers decreased by $3.11 \%$ and $10.67 \%$ respectively in nearly 40 years.

Nyainqentanglha is divided into eastern and western sections in the headwater of Lhasa River (Wu et al., 2002). The eastern Nyainqentanglha is controlled by the Southwest Indian Ocean monsoon with warm-humid climate. Because warm-humid climate is forced by the steep terrain to uplift, here becomes one of most rainfall area and the wettest region in the Tibetan Plateau. The precipitation can reach to $3000 \mathrm{~mm}$ around in some glacier areas (Jiao et al., 2005) and glacier area basically accounts for more than $90 \%$ of total glacier area in Nyainqentanglha. Here, neotectonics is strong, and tectonic seismic activity is also frequent and intense. The earthquake often destroyed the stability of glacier body and moraine dam and made own state of glacial lake lose balance. And, it also damaged geotechnical stability, made it generate adequate loose materials, which provides material source condition for GLOF mudslides.

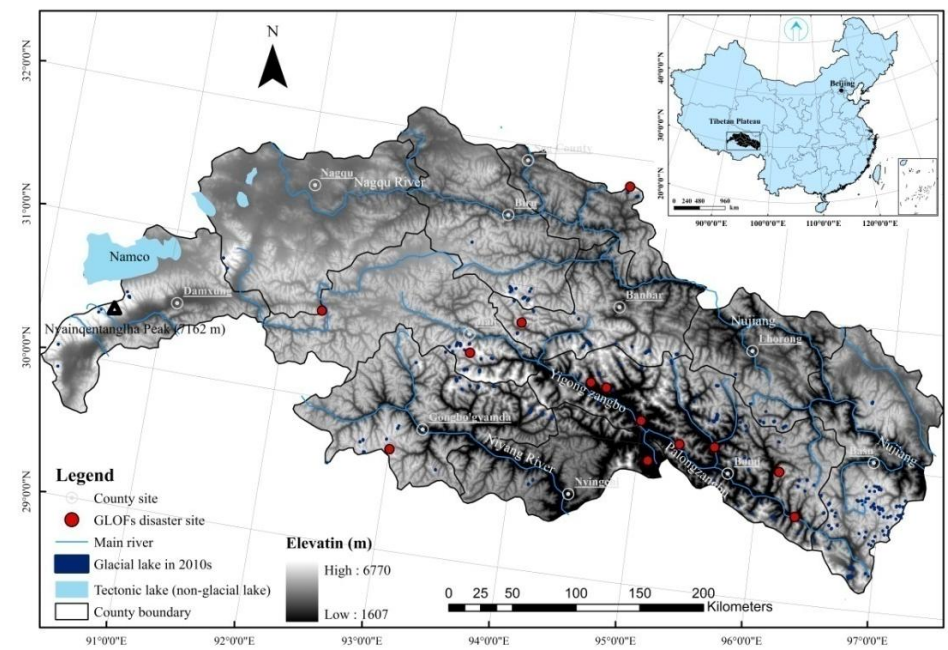

Fig. 1 Location of the Nyainqentanglha Mountain showing the major river basins, glacial lake distribution, recorded GLOF sites and 11 county boundaries in Southeastern Tibetan Plateau

The study area is administratively divided into 11 counties: Sog, Nagqu, Damxung, Lhorong, Nyingchi, Jiali, Gongbo'gyamda, Bomi, Banbar, Biru, Basu County (Fig. 1). Most communities located in remote areas away from glacial lakes are often within the reach of GLOFs. In 2013, the population and regional GDP were 550, 000 and RMB 3.63 billion, respectively, accounting for $17.63 \%$ and $4.44 \%$ of total population and GDP of the Tibet Autonomous Region. Local residents' perception of the threat from remote glacial lake is relatively weak, and their ability to prevent and adapt to disaster is extremely limited, which provides a disaster-affected body conditions for the formation of GLOF disaster. It can be predicted that GLOF impacts will likely extend farther downstream as glaciers continue to retreat in the next few decades.

\section{Data and Processing}

\subsection{Date}

The data for this study consist of Landsat imagery obtained on multiple dates in the 1990s and 
Nat. Hazards Earth Syst. Sci. Discuss., doi:10.5194/nhess-2016-300, 2016

Manuscript under review for journal Nat. Hazards Earth Syst. Sci.

Published: 27 September 2016

(c) Author(s) 2016. CC-BY 3.0 License.

$\begin{array}{r}\text { Natural Hazards } \\ \text { and Earth System } \\ \text { Sciences } \\ \hline\end{array}$

Discussions
114

115

116

117

118

119

120

121

122

123

124

125

126

127

128

129

130

131

132

133

134

135

136

137

138

139

140

141

142

143

144

145

146

147

148

149

150

151

152

153

154

155 2010s, topographic maps, ASTER DEMs in 2009, and statistical data concerning the socio-economic system in 2014. Image data are used to analyze the spatial and temporal variation of glacial lakes and to identify their potential risk, whereas regional socio-economic data are used to assess exposure, vulnerability and adaptation capacity in hazard-affected regions. The Nyainqentanglha, especially, the middle-eastern region, is affected by the southwes monsoon with humid and heat climate, thus the region is covered with cloud during most of month in a year. To avoid cloud and snow cover during the monsoon and ensure minimal snow coverage, we selected as far as possible 22 satellite images as far as possible with $<10 \%$ (5\% is an ideal parameter) cloud cover acquired between June and October in the 1990s and 2010s. The study area was observed with 22 Landsat TM and ETM+ images with a spatial resolution of $30 \mathrm{~m}$ (http://glovis.usgs.gov), in which some Landsat-7 image strips are elimineted by using Multi-Image window fixed regression model ( that is, image strip or gap is filled by using multi-view remote sensing data with different time and a local regression analysis method, in which the area of regression region is a fixed value). Raw data for the socio-economic system were obtained from Statistical Yearbooks of all counties and the Atlas of China Traffic (Starmap Publishing House, 2006). The data were quantified using different units. To compare them, the original data on evaluation factors need to be rendered dimensionless by transforming the range. Based on the method reported by previous studies (Zhao et al., 2006), we used normalization to standardize these data from various sources.

\subsection{Detection of moraine-dammed lakes}

The accuracy of glacial lake delineation is mostly determined by glacier and snow around the lake or within the hillshade covered area, and by cloud cover over glacial lake. In the study, glacial lake boundaries, distributions and evolutions were investigated using detailed delineations and measurements of satellite-derived imagery. Images, when rectified, were further processed before interpretation, by comparing different band combinations. This showed that the standard false-color composite (FCC) images made from combining bands 4 , 3 and 2 were most conducive for identifying glacial lake boundaries. When lakes were frozen and snow covered, a visual inspection was necessary to distinguish snow covered glacial lakes, with the help of 7, 5 and 2 band composites. Lakes are assumed to be areas where the slope is $<10 \%$ (Gardelle et al., 2011). Then, all images need to match with ERDAS software and images from two periods (1990s and 2010s), and need geographic registration to assure overlap with the ASTER GDEM of 2009 (http://datamirror.csdb.cn).

Based on the image interpretation, all glacial lakes were delineated manually from digitized topographic maps of 1976 and/or FCC satellite images, pixel by pixel, in ArcGIS 9.2 with the help of Google Earth imagery and field research. When the cloud cover is over 5\%, multi-source image and topographic map are used to correct glacial lake boundaries. Finally, the vector layers of glacial lakes in 1990s and 2010s were obtained and attribute data: lake type, length, area and altitude were established by eyewitness interpretation and geographic calculation. The measurement accuracy of glacial lake area from spatial data is limited by sensor resolution and manual digitizing. According to Wang et al. (2011) and Wang et al. (2015), the uncertainty in co-registration of multitemporal images can be calculated by

$$
U_{L}=\sqrt{\sum \lambda^{2}}+\sqrt{\sum \sigma^{2}}
$$




$$
U_{A}=\frac{\left(2 U_{L}\right)}{\sqrt{\sum \lambda^{2}}} \times \sum \lambda^{2} \times \sum \sigma^{2}
$$

where $U_{L}$ is the linear uncertainty $(\mathrm{m}), U_{A}$ is the glacial lake's area uncertainty $\left(\mathrm{m}^{2}\right), \lambda$ is the original pixel resolution of each individual image $(\mathrm{m})$ and $\sigma$ is the co-registration error of each individual image to topographic maps (m). Accordingly, the maximum error in coregistration $\left(U_{A}\right)$ for changes in glacial lakes from the 1990s to the 2010s was calculated as $\pm 0.015 \mathrm{~km}^{2}$.

\subsection{Identification of potentially dangerous glacial lakes}

Generally, glacial lake failure comes from external (ice/snow/rock avalanches, landslides, rainstorm, glacier advance, earthquake, snow and ice melting) and internal incentives (the ablation of buried ice within moraine dam, the release of lake water inside ice body, piping, seepage, etc). According to failure mechanisms, GLOF can be divided into five categories: 1) The outburst flood is triggered by wave overtopping moraine-dam, 2) by seepage/piping; 3) by flow water erosion from next valley; 4) by earthquake; 5) by various combined factors.

Based on above analysis and taking into account the availability of data obtained, this study selected only moraine-dammed lake area $\left(>0.02 \mathrm{~km}^{2}\right)$, the rate of lake area increase $(>20 \%)$, the distance between lake and glacier snout $(<500 \mathrm{~m})$ and whether or not there were settlements downstream as rough evaluation criteria to determine whether a lake is dangerous or not. Lake area affects the volume of stored water and the maximum outburst flood volume. Rapid changes in lake area will upset the hydric balance, thereby promoting moraine-dammed lake outburst. The distance between lake and glacier terminus will determine the amount of snow/ice/rock avalanches collapsed into the lakes, which will result in the displacement waves and further trigger an outburst flood (Awal et al., 2010; Wang et al., 2015).

\subsection{Establishment of GLOF disaster risk assessment system}

Based on previous findings on natural disaster risk (Catani et al., 2005; Nadim and Kjekstad, 2009; Carey et al., 2012), GLOF disaster risk can be defined as a combination of the likelihood of a major outburst event occurring (i.e. hazard), exposure to an outburst event, vulnerability (i.e. susceptibility) of exposed elements (i.e. people, property) and adaptation capacity for preventing and responding to an outburst event (i.e. management ability) (Wang et al., 2015)(Fig. 2). Unlike risk, a GLOF disaster is an actual occurrence, rather than a potential threat (Smith, 2001), so it may simply be defined as the realization of a threatening glacial lake outburst event affecting ecological, economic and social systems downstream. 
Nat. Hazards Earth Syst. Sci. Discuss., doi:10.5194/nhess-2016-300, 2016

Manuscript under review for journal Nat. Hazards Earth Syst. Sci.

Published: 27 September 2016

(c) Author(s) 2016. CC-BY 3.0 License.

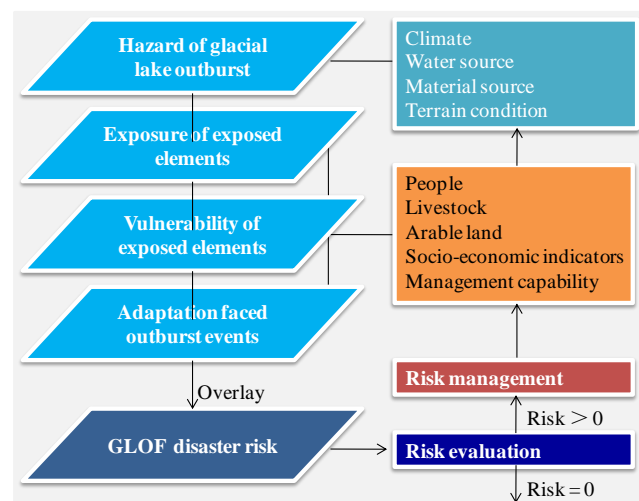

Risk $=0$ (hazard $=0$ and/or exposure $=0$ and/or vulnerability $=0$ and/or adaptation $=0$ ) There is no need for risk management

Fig. 2 The component of GLOF disaster risk and risk management process

Based on the above analysis, a conceptual framework of GLOF disaster risk was established. The risk assessment conceptual framework contains three hierarchies: objective layer $(A)$ (integrated risk), principal layer $(B)\left(B_{1}, B_{2}, B_{3}, B_{4}\right)$ and index layer $(C)\left(C_{1}-C_{15}\right)$ (Specific factor analysis are shown in the study by Wang et al., 2015) (Table 1), in which Hazard $\left(B_{1}\right)$ reflects directly the possibility or probability of a moraine dammed lake outburst and the severity of threats and harms to downstream residents, property and ecosystems. Exposure $\left(B_{2}\right)$ describes spatial distribution and numbers of exposed elements and expressed generally by the quantity and density of exposed elements. Vulnerability $\left(B_{3}\right)$ reveals the susceptibility of exposed elements and the extent of damage and losses in population, property, and other elements affected by GLOFDs. Adaptation capacity $\left(B_{4}\right)$ reflects early monitoring, warning and forecasting levels of moraine dammed lake outburst and defense capabilities to reduce lake water level, regional exposure and vulnerability facing to the threaten from lake outburst. Among all indicator, road level $\left(C_{11}\right)$ is reflected by proportion of below provincial highways in the total mileage, while building level $\left(C_{12}\right)$ is replaced by the net income of regional farmers and herdsmen for the lack of data.

Table 1. GLOF disaster risk assessment indicator system and weights

\begin{tabular}{|c|c|c|c|c|}
\hline Objective layer $(A)$ & Principle layer $(B)$ & Index layer $(C)$ & Unit & Weight \\
\hline \multirow{11}{*}{$\begin{array}{c}\text { Integrated risk } \\
\text { index } \\
\left(R I_{G L O F D}\right)\end{array}$} & \multirow{3}{*}{ Hazard $\left(B_{l}\right)$} & PDGLs Number $\left(C_{l}\right)$ & - & 0.061 \\
\hline & & PDGLs Area $\left(C_{2}\right)$ & $\mathrm{km}^{2}$ & 0.186 \\
\hline & & Area change of PDGLs $\left(C_{3}\right)$ & $\%$ & 0.124 \\
\hline & \multirow{5}{*}{ Exposure $\left(B_{2}\right)$} & Population density $\left(C_{4}\right)$ & person $\mathrm{km}^{-2}$ & 0.053 \\
\hline & & Livestock density $\left(C_{5}\right)$ & $10^{4}$ & 0.036 \\
\hline & & The cultivated area $\left(C_{6}\right)$ & $\mathrm{km}^{2}$ & 0.037 \\
\hline & & Density of road network $\left(C_{7}\right)$ & $\mathrm{km} \mathrm{km}^{-2}$ & 0.033 \\
\hline & & Density of agricultural economy $\left(C_{8}\right)$ & Yuan $\mathrm{km}^{-2}$ & 0.040 \\
\hline & \multirow{3}{*}{ Vulnerability $\left(B_{3}\right)$} & Proportion of rural population $\left(C_{9}\right)$ & $\%$ & 0.069 \\
\hline & & Percentage of small livestock $\left(C_{10}\right)$ & $\%$ & 0.038 \\
\hline & & Road level $\left(C_{11}\right)$ & $\%$ & 0.018 \\
\hline
\end{tabular}




\begin{tabular}{llll}
\hline & Building level $\left(C_{12}\right)$ & $10^{4}$ Yuan & 0.021 \\
\cline { 2 - 4 } & Regional GDP $\left(C_{13}\right)$ & $10^{8}$ Yuan & 0.115 \\
Adaptation capacity $\left(B_{4}\right)$ & Financial evenue share of GDP $\left(C_{14}\right)$ & $\%$ & 0.092 \\
& Density of fixed assets investment $\left(C_{15}\right)$ & $10^{4} \mathrm{Yuan} \mathrm{km}^{-2}$ & 0.073 \\
\hline
\end{tabular}

The study determined an index weight by the analytic hierarchy process (AHP) (Saaty, 1977). This process included five basic steps: 1) design of questionnaire, 2) calculation of a pairwise comparison matrix, 3) estimation of relative weighting values (a scale from 1 (two components contribute equally to GLOF disaster risk) to 9 (one component predominates completely over the other in causing GLOF disaster occurrence) was used to compare pairs of components), 4) examination of consistency and 5) aggregation of the weights to determine a ranking of decision alternatives (Rachel et al., 2001). The weight values used for the GLOF disaster risk are shown in Table 1. The weight values of the hazard, exposure, vulnerability and adaptation capacity factors are $0.37,0.20,0.15$ and 0.28 , respectively. The main (top six) indicators of index layer are arranged as follows: PDGL area, rate of PDGL area change, regional GDP, revenue share of GDP, density of fixed assets investment and proportion of rural population. The contribution degree of the top six factors was up to $66 \%$.

\subsection{GLOF disaster risk assessment model}

GLOF disaster risk generally has a positive correlation with hazard, exposure and vulnerability, while it is negatively correlated with adaptation capacity. According the past study by Wang et al. (2015), we developed the following equations to determine the degree of risk of GLOF disaster by integrating the assessment method of other natural disaster risks:

$$
I_{G L O F D R}=(H \times E \times V) / A
$$

$$
H(E, V, A)=\sum_{i}^{m} w_{i} x_{i j}^{\prime}
$$

$$
x_{i j}^{\prime}=10 \times x_{i j} / x_{\max }
$$

where $I_{G L O F D R}$ (index of GLOF disaster risk) indicates the degree of GLOF disaster risk (generally, the higher the value, the greater the degree of $G L O F$ disasters risk) and $H, E, V$ and $A$ are the hazard, exposure, vulnerability and adaptation capability factors $(A>0) . m$ is the number of indicators reflecting hazard, exposure, vulnerability and adaptation capability factors. $x_{i j}, x_{i j}^{\prime}$ refer to the unscaled and scaled values of the $i$ th indicator of Index layer $(C)$ in the $j$ th county $\left(0<x_{i j}^{\prime}<10\right) . w_{i j}$ is the weight of the $i$ th indicator of Index layer $(C)$ in the jth county relative to Objective layer $(A)\left(0<w_{i}<1\right)$ (Table 1$)$ and is obtained by $A H P$. $x_{\max }$ is the maximal value of the indicators $x_{i j}$. A large value of $x_{i j}^{\prime}$ means that this factor has a stronger impact on GLOF disaster risk, whereas a small value of $x_{i j}^{\prime}$ suggests the impact is less.

Using $I_{G L O F D R}$, the degrees of GLOF disaster risk can be compared. From $I_{G L O F D R}$, it is found that when $H \times E \times V=0, I_{G L O F D R}=0$. With adaptation capability $A \neq 0$ decreases, the $I_{G L O F D R}$ value increases. When the hazard, exposure, and vulnerability are reduced and management ability 
Nat. Hazards Earth Syst. Sci. Discuss., doi:10.5194/nhess-2016-300, 2016

Manuscript under review for journal Nat. Hazards Earth Syst. Sci.

Published: 27 September 2016

(c) Author(s) 2016. CC-BY 3.0 License.

increases, $I_{\text {GLOFDR }}$ decreases.

\section{Results and analysis}

\subsection{Distribution and evolution of moraine-dammed lakes}

In the Nyainqentanglha, 132 moraine-dammed lakes $\left(>0.02 \mathrm{~km}^{2}\right)$ with a total area of 38.235 $\mathrm{km}^{2}$ were detected from remotely sensed data in the 2010s. The areas of moraine-dammed lakes range from $0.02 \mathrm{~km}^{2}$ to $4.10 \mathrm{~km}^{2}$, at altitudes between 3100 and $5500 \mathrm{~m}$. As shown in Figure 3, 132 lakes were distributed in 11 counties in the 2010s. Of these, Basu has the most lakes (45), 34.09\% of the total number in the study area, and Bomi has the largest lake area $\left(10.85 \mathrm{~km}^{2}\right), 28.38 \%$ of the total moraine-dammed lake area. Gongbo'gyamda has 13 lakes with a total area of $3.995 \mathrm{~km}^{2}$. Basu and Bomi together account for $62.88 \%$ of the total number of lakes and $53.46 \%$ of the total lake area. Jiali and Banbar also have relatively large $\left(3.119 \mathrm{~km}^{2}\right.$ and $\left.6.321 \mathrm{~km}^{2}\right)$, yet lake area is relatively small $\left(<1.60 \mathrm{~km}^{2}\right)$ in Sog, Nagqu, Lhorong, Nyingchi and Biru County.

In the past 20 years, the total area of moraine-dammed lakes has expanded by $22.72 \%$, from $29.55 \mathrm{~km}^{2}$ in the $1990 \mathrm{~s}$ to $38.24 \mathrm{~km}^{2}$ in the $2010 \mathrm{~s}$. The expansion rate was higher than in the Nepal-Bhutan and Western India-Pakistan-Afghanistan Himalayas $\left(-0.08\right.$ to $\left.0.45 \mathrm{~km}^{2} / \mathrm{a}\right)$ between 1990 and 2009, while lower significantly $0.57 \mathrm{~km}^{2} / \mathrm{a}$ in the central Chinese Himalayas from 1990 to 2010 (Wang and Zhang, 2013). Among the 11 counties, the magnitude of lake area increase between the 1990s and 2010s has been largest in Banbar county (387.73\%), followed by Damxung (51.69\%), Basu (23.06\%) and Bomi (16.26\%). In contrast, lake area in Biru, Jiali and Lhorong decreased significantly by $14.71 \%, 8.91 \%$ and $1.25 \%$, respectively. In other counties, the magnitude of lake area change was $1-11 \%$. It is apparent that lake area variations in the study area have regional differences (Fig. 3). It is noteworthy that the area of 22 moraine-dammed lakes in the study area decreased by $>20 \%$, which means that these lakes have likely burst without detection.
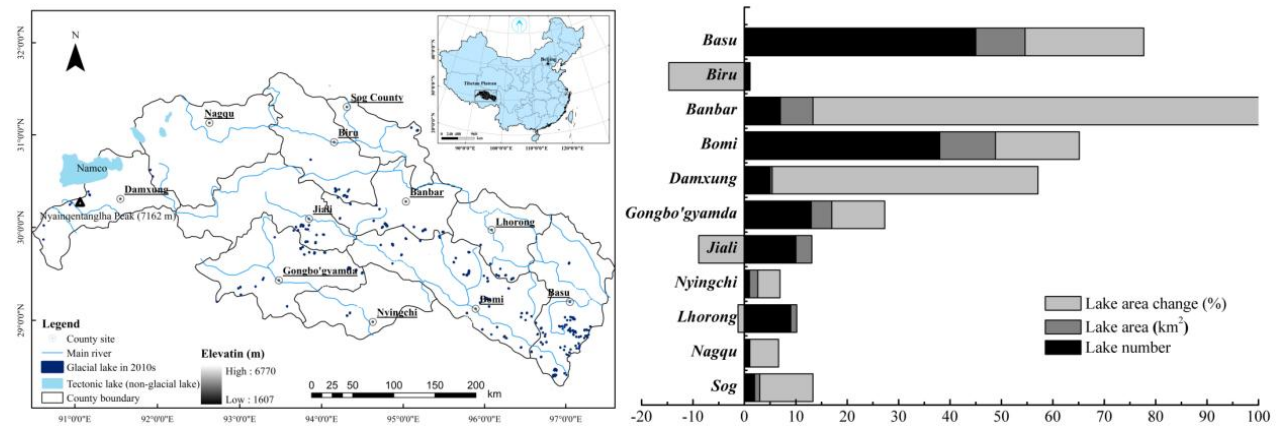

Fig. 3 Distribution and evolution of moraine-dammed lakes in the Nyainqentanglha

\subsection{Distribution and evolution of PDGLs}

The results show that 54 moraine-dammed lakes with a total area of $17.53 \mathrm{~km}^{2}$ in the $2010 \mathrm{~s}$ are identified as PDGLs (Table 2). All PDGLs with an area $\geq 0.02 \mathrm{~km}^{2}$ are $<500 \mathrm{~m}$ from the glacier terminus and growth rates of all PDGLs have been more than $20 \%$ in the past two decades. PDGLs comprise $40.91 \%$ and $59.33 \%$ of the total number and area respectively, of moraine-dammed lakes in the study area.

Table 2. Distribution and variation of PDGLs in 11 counties in the study area 
Nat. Hazards Earth Syst. Sci. Discuss., doi:10.5194/nhess-2016-300, 2016

Manuscript under review for journal Nat. Hazards Earth Syst. Sci.

Published: 27 September 2016

(c) Author(s) 2016. CC-BY 3.0 License.
Natural Hazards and Earth System

Sciences

Discussions

\begin{tabular}{|c|c|c|c|c|c|}
\hline \multirow{2}{*}{ County name } & \multirow{2}{*}{\multicolumn{2}{|c|}{$\begin{array}{l}\text { PDGL number in } \\
2010 \mathrm{~s}\end{array}$}} & \multicolumn{3}{|c|}{ Lake area $\left(\mathrm{km}^{2}\right)$} \\
\hline & & & $1990 \mathrm{~s}$ & $2010 \mathrm{~s}$ & Change rate $(\%)$ \\
\hline Sog & & 1 & 0.080 & 0.097 & 22.00 \\
\hline Nagqu & & 0 & 0.000 & 0.000 & 0.00 \\
\hline Lhorong & & 1 & 0.227 & 0.323 & 42.60 \\
\hline Nyingchi & & 0 & 0.0000 & 0.000 & 0.00 \\
\hline Jiali & & 5 & 0.2203 & 0.342 & 55.23 \\
\hline Gongbo'gyamda & & 4 & 0.447 & 1.076 & 140.50 \\
\hline Damxung & & 4 & 0.18 & 0.300 & 59.30 \\
\hline Bomi & & 12 & 2.519 & 4.175 & 64.90 \\
\hline Banbar & & 7 & 1.308 & 6.864 & 424.68 \\
\hline Biru & & 1 & 0.050 & 0.087 & 73.80 \\
\hline Basu & & 18 & 2.142 & 4.261 & 98.90 \\
\hline Total & & 54 & 7.17 & 17.53 & 144.31 \\
\hline
\end{tabular}

272 From the 1990 s to the 2010s, the total area of PDGLs increased significantly by $144.31 \%$, whereas non-PDGLs decreased slightly by $4.06 \%$ in the study area in the same period.

PDGLs are mainly distributed in the eastern Nyainqentanglha, and are rare in the western region (Table 3). Basu has the most PDGLs (18), followed by Bomi (12) and Banbar (8). PDGLs in these three counties account for 73.37 of the total number of PDGLs in the study area. Most PDGLs are in contact with parent glaciers and are considered large enough to cause damage downstream if they outburst (Tables 2, 3). Table 3 lists 20 PDGLs with an area $>0.20 \mathrm{~km}^{2}$ and a rate of lake area increase $>20 \%$.

Table 3. Distribution and evolution of 20 PDGLs with an area $>0.20 \mathrm{~km}^{2}$ in the $2010 \mathrm{~s}$ and area increase by $>20 \%$ in the Nyainqentanglha in the past 20 years

\begin{tabular}{|c|c|c|c|c|c|c|c|}
\hline \multirow{2}{*}{ Lake name } & \multirow{2}{*}{ Location } & \multirow{2}{*}{ Lon. $\left({ }^{\circ}\right)$} & \multirow{2}{*}{ Lat. $\left({ }^{\circ}\right)$} & \multicolumn{2}{|c|}{ Area $\left(\mathrm{km}^{2}\right)$} & \multirow{2}{*}{$\begin{array}{l}\text { Area change (\%) } \\
2010 \text { s to } 1990 \text { s }\end{array}$} & \multirow{2}{*}{$\begin{array}{l}\text { Distance to glacier } \\
\text { in the } 2010 \mathrm{~s}(\mathrm{~m})\end{array}$} \\
\hline & & & & $1990 \mathrm{~s}$ & $2010 \mathrm{~s}$ & & \\
\hline \multirow[t]{2}{*}{ Samuco } & Banbar & 94.49 & 30.66 & 0.146 & 4.10 & 2709.74 & 0 \\
\hline & Basu & 96.82 & 29.30 & 1.111 & 2.67 & 140.20 & 0 \\
\hline \multirow[t]{2}{*}{ Dongguanlaco } & Bomi & 94.60 & 30.45 & 0.709 & 1.43 & 101.40 & 0 \\
\hline & Bomi & 95.18 & 30.60 & 0.677 & 1.03 & 52.39 & 0 \\
\hline \multirow[t]{2}{*}{ Suquco } & Banbar & 94.96 & 30.65 & 0.191 & 0.79 & 315.02 & 0 \\
\hline & Banbar & 95.22 & 30.66 & 0.494 & 0.62 & 26.37 & 0 \\
\hline Jiongpuco & Banbar & 94.44 & 30.63 & 0.209 & 0.54 & 160.24 & 0 \\
\hline \multirow[t]{2}{*}{ Jiwenco } & Jiali & 93.63 & 30.36 & 0.432 & 0.54 & 24.45 & 0 \\
\hline & Gongbo'gyamda & 94.27 & 30.10 & 0.199 & 0.53 & 166.62 & 0 \\
\hline Longlikunzeco & Basu & 96.59 & 29.73 & 0.315 & 0.48 & 52.84 & 0 \\
\hline \multirow[t]{8}{*}{ Boquco } & Banbar & 94.99 & 30.66 & 0.151 & 0.46 & 201.88 & 0 \\
\hline & Gongbo'gyamda & 93.77 & 30.26 & 0.154 & 0.42 & 175.22 & 0 \\
\hline & Lhorong & 96.07 & 30.27 & 0.227 & 0.32 & 42.60 & 300 \\
\hline & Bomi & 94.73 & 30.35 & 0.124 & 0.30 & 138.98 & 0 \\
\hline & Bomi & 95.64 & 29.80 & 0.213 & 0.26 & 22.93 & 50 \\
\hline & Basu & 96.50 & 29.47 & 0.146 & 0.26 & 76.15 & 0 \\
\hline & Bomi & 95.60 & 30.24 & 0.170 & 0.21 & 22.28 & 0 \\
\hline & Bomi & 95.40 & 30.34 & 0.165 & 0.20 & 21.86 & 0 \\
\hline
\end{tabular}




\subsection{Assessment and regionalization of GLOF disaster risk}

When analyzing GLOF disaster risks, the formation mechanism of the risks must be followed. The four main factors that form GLOF disaster risk should be analyzed separately. We calculated hazard, exposure, vulnerability risk and adaptation capability, using Eqn (4). Regionalization maps are drawn by the ArcGIS equal interval classification method (Fig. 4). The regionalization results show that hazard levels are 'very low' or 'low' in Nagqu, Damxung, Biru, Jiali and Sog, Lhorong and Nyingchi. The regions with moderate and high GLOF disaster hazard levels are located in Bomi, Basu and Gongbo'gyamda, while the highest hazard zones are concentrated in Banbar. Overall, the larger PDGL area has a higher hazard level. For example, PDGL areas in Banbar, Basu and Bomi were 6.952, 4.621 and $4.045 \mathrm{~km}^{2}$ respectively in the 2010s, with PDGL area increasing by over $64 \%$ everywhere (Fig. 4 (a); Table 3). In contrast, Gongbo'gyamda has the fewer lake (4) and the PDGL area $\left(1.076 \mathrm{~km}^{2}\right)$, but the fastest-growing lake area $(140.5 \%)$. Thus, Gongbo'gyamda has the larger GLOF disaster hazard level (Fig. 4(a)).

Figure 4(b) shows the spatial distribution of exposure levels across the study area. Overall, the exposure level of GLOFs increases from north to south, except for Jiali and Bomi. Sog, Lhorong, Nagqu and Banbar have high and very high degrees of exposure, in which Lhorong has the higher density of population, livestock and agricultural economy (6.11 persons $\mathrm{km}^{-2}$, 23.92 sheep units $\mathrm{km}^{-2}$ and $3.04 \times 10^{4} \mathrm{RMB} \mathrm{km}^{-2}$ ). By contrast, other counties have middle, low and very low degrees of exposure, especially Gongbo'gyamda, Basu, Jiali, Bomi and Damxung. Among these counties, Damxung has the lowest density of population and livestock $\left(<1\right.$ person $\mathrm{km}^{-2}$ and 2.92 sheep units $\left.\mathrm{km}^{-2}\right)$.
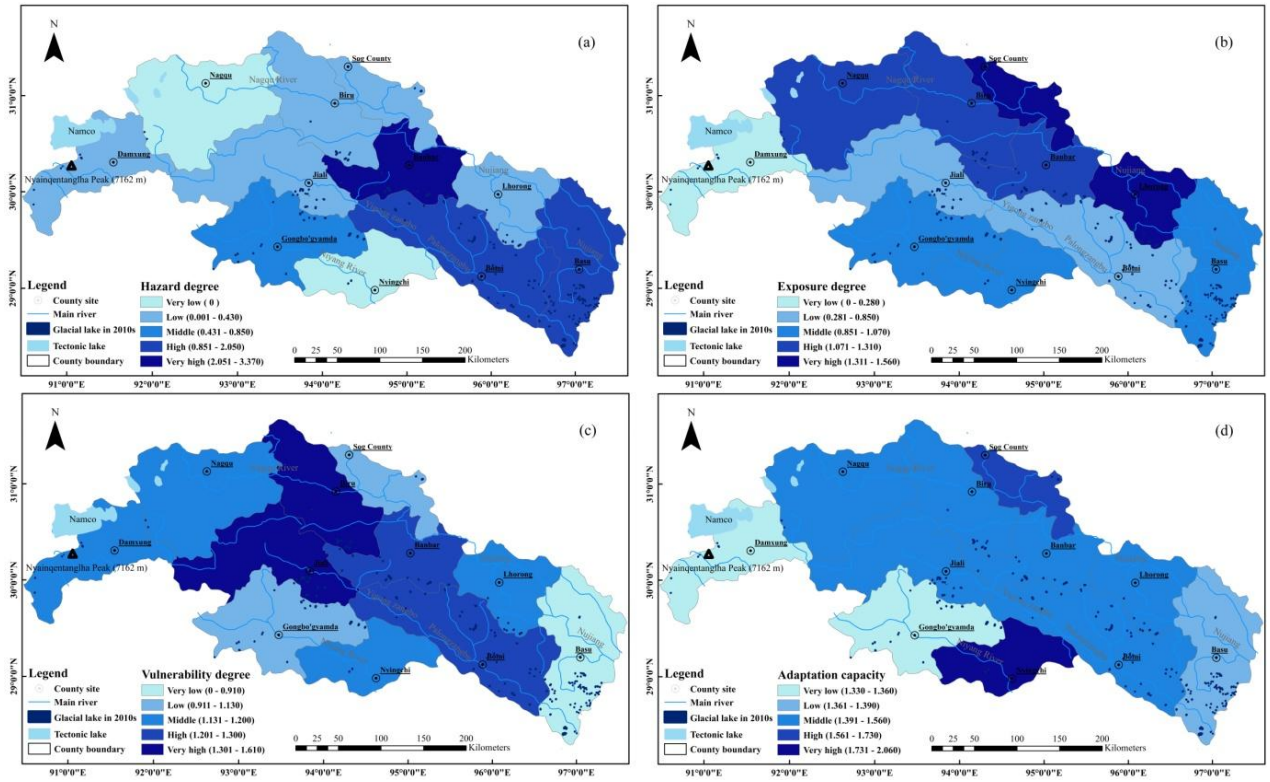

Fig. 4 Map of hazard degree (a), exposure degree (b), vulnerability degree (c) and adaptation capability degree (d) for 11 counties in the Nyainqentanglha

Figure 4(c) demonstrates that the GLOF disaster vulnerability level is higher in the middle 
Nyainqentanglha than the surrounding areas with Biru and Jiali having very high, and Banbar and Bomi having high vulnerability levels. Of 11 counties, Gongbo'gyamda has the highest proportion of agricultural population (93\%) and the smallest proportion of livestock (5\%), while Basu and Damxung have the lowest level of roads and housing construction. A lower proportion of agricultural population and small livestock, a higher road and construction level (e.g. roads and housing) will greatly reduce the vulnerability of exposed elements and enhance their resilience.

Economic base determines the ability of disaster prevention and mitigation. In 2013, GDP and financial revenue of the 11 counties in the Nyainqentanglha reached 36.34 and 24.6 billion Yuan, accounting for $20.3 \%$ and $4.44 \%$ respectively, of the Tibet Autonomous Region totals. Of this, the GDP of Jiali, Sog and Basu county was $<0.20$ billion RMB. Importantly, the area-density of fixed asset investment in Biru and Damxung counties is $<30,000 \mathrm{RMB} \mathrm{km}^{-2}$. Figure 4(d) indicates that adaptation capability levels are very low in Damxung and Gongbo'gyamda and low in Basu. The regions with moderate and high levels of GLOF disaster adaptation capability are located in Nagqu, Biru, Jiali, Lhorong and Bomi, whereas the very high adaptation capability zones are concentrated in the southern Nyingchi.

\subsection{Assessment and regionalization of integrated GLOF disaster risk}

After each of the four main factors forming GLOF disaster risk is analyzed, the degree of integrated GLOF disaster risk for the 11 counties is assessed. The spatial distribution of GLOF disaster risk degree in the study area is shown in Figure 5. The results show that the maximum, mean and minimum regional $I_{\text {GLOFDR }}$ are 3.74, 0.63 and 0 respectively. Based on the above results, the $I_{\text {GLOFDR }}$ values were used as the criteria for zoning the integrated GLOF disaster risk degree in the study area. According to the $R I_{G L O F D}$ value and the historical data of GLOF disasters, risk was classified into the following five grades: very low risk: $I_{\text {GLOFDR }}<$ 0.100; low risk: $0.101 \leq I_{\text {GLOFDR }}<0.360$; middle risk: $0.361 \leq I_{\text {GLOFDR }}<0.630$; high risk: $0.631 \leq I_{\text {GLOFDR }}<1.380$; and very high risk: $1.381 \leq I_{\text {GLOFDR }} \leq 3.740$.

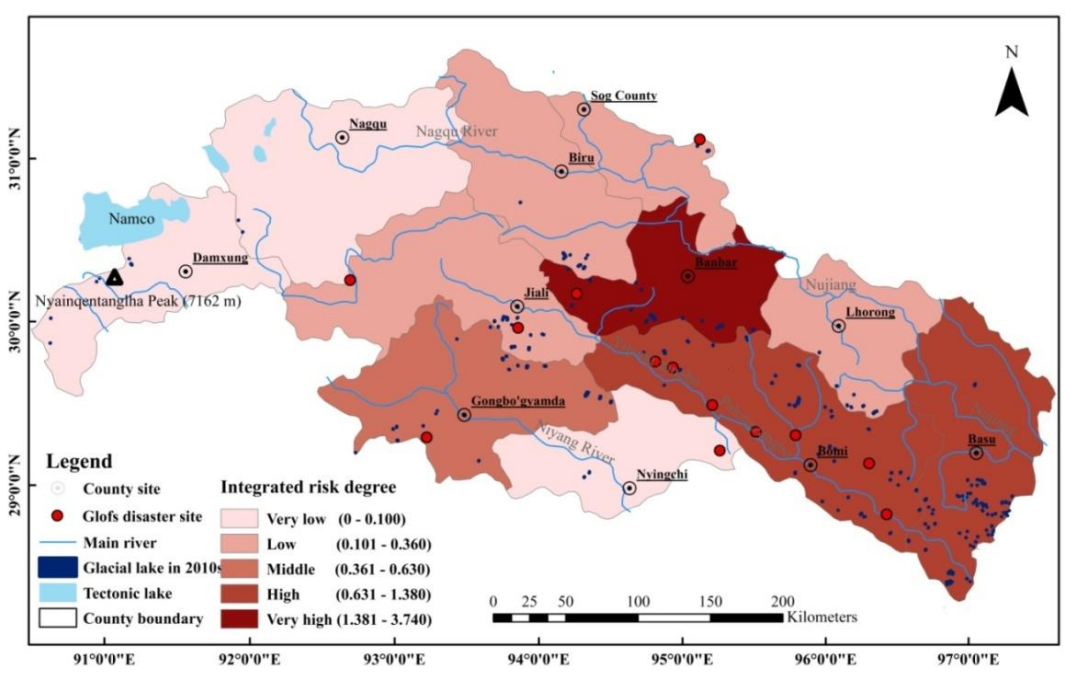

Fig. 5 Map of risk degree of GLOFDs in 11 counties within the Nyainqentanglha

Figure 5 shows that Banbar, Bomi, Basu and Gongbo'gyamda are in the middle, high and very 
Nat. Hazards Earth Syst. Sci. Discuss., doi:10.5194/nhess-2016-300, 2016

Manuscript under review for journal Nat. Hazards Earth Syst. Sci.

Published: 27 September 2016

(c) Author(s) 2016. CC-BY 3.0 License.

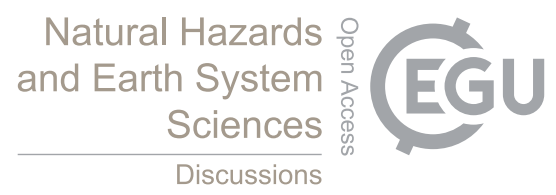

high-risk zone, in which Banbar has the highest $I_{\text {GLOFDR }}$ (3.74) with highest hazard degree (3.37), high exposure degree (1.27) and low vulnerability degree (1.50). It is worth noting that at least 14 GLOF disasters have occurred in the Nyainqentanglha since 1935, in which the high and very high risk zone includes $57.14 \%$ of GLOF disasters in the study area, most of these accounted for by outbursts from Bugyai (1991) in Sog, Mitui-Cho (1988) in Bomi, Recireco (2013) in Jiali. On the whole, the high and very high risk zones mainly focus on the central and central-eastern Nyainqentanglha, whereas low and very low-risk zones are in the western Nyainqentanglha.

The GLOF disaster risk assessment results are consistent with the distribution of historic disaster sites across the Nyainqentanglha. Accordingly, the research results can provide practical guidelines and the basis for policy decisions on regional GLOF disaster prevention and mitigation. Specifically, local governments should prioritize high, very high-risk zones in the process of GLOF disaster prevention and mitigation, and should take medium and high risk zones as key areas for monitoring moraine-dammed lake change.

\section{Discussion and Conclusions}

Nyainqêntanglha is another high-frequency and severely affected area of GLOF disasters besides Peruvian Andes and the Himalayas in the world. However, risk management measures is extremely limited in this area, the potential damage from GLOF disasters is worrisome. It is very difficult or expensive to control glacial lake outburst (hazard) and it is also difficult to remove its danger, but the exposure of the region and vulnerability of exposed elements in the downstream can be reduced by improving adaptation capacity and risk management level (that is, early warning and forecasting, disaster reserve, disaster prevention engineering, medical conditions, emergency management, disaster insurance). Mainstream in the past emphasized the natural properties of disasters mechanism, but the current risk identification of disaster, risk control, disaster prevention and mitigation have become the focus of attention, this proactive risk assessment and management will certainly help to avoid and mitigate the potential impacts or threat from GLOF disasters. Of course, the reduction of exposure and the improvement of vulnerability through early warning and risk management would be more realistic given the limited local budget available to respond to GLOF disaster except for engineering measures. Risk management should adjust measures to differing local conditions, emphasize and focus on high-risk areas. Government managers should distinguish the degrees of gravity and urgency of outburst damage, and then put forward risk prevention and control programs batch by batch and stage by stage to PDGLs with high-risk. Especially, during planning of mountainous village and town, infrastructure construction, major engineering decisions, government managers or operating unit must complete disaster risk assessment planning before construction, all buildings, roads and infrastructure should try to keep away from the PDGLs in order to avoid unnecessary damage to person and property downstream.

Reasonable engineering measures by reducing lake capacity and reinforcing moraine dam are most efficient or most direct ways to relieve or control risk, and these measures depend mainly on the condition of moraine dam, outburst risk, engineering difficulties and so on. For lakes with relatively stable dam, outburst will not occur in short-term, while outburst has great potential harm, lake water level should be mainly reduced by using pumping and siphon drainage. For lakes that moraine dam has a weak stability, outburst will not exist in 
Nat. Hazards Earth Syst. Sci. Discuss., doi:10.5194/nhess-2016-300, 2016

Manuscript under review for journal Nat. Hazards Earth Syst. Sci.

Published: 27 September 2016

(c) Author(s) 2016. CC-BY 3.0 License.

medium-long term, and its outburst is greatly harmful to the downstream, we must take most effective ways, such as strengthen dam body, build channels, culverts, tunnels for preventing surge overtopping, eroding drain port and reducing storage capacity. For lakes whose moraine dams are relatively weakness, outburst will occur in a short time, its outburst risk has greatly harmful effects to the downstream, and the engineering measures and construction is relatively difficult to the moraine dam and investment of the engineering measures is too large, they should be advised to forcibly relocate the residents of the disaster-affected area.

Especially, prevention and mitigation of GLOF disasters is a systems engineering with multi-lateral linkage, consultation, participation and collaboration. Governments at all levels, experts, enterprises, NGOs, community residents etc. should participate in the whole process of prevention and reduction of disasters, and then form a multi-sided linkage mechanism of disaster prevention and reduction with information sharing, resource sharing, coordination and distribution of responsibilities. Therefore, the reduction of exposure and the improvement of vulnerability through early warning and risk management would be more realistic given the limited local budget available to respond to GLOF disaster except for engineering measures.

\section{References}

Awal, R., Nakagawa, H., Fujita, M., Kawaike, K., Baba, Y. and Zhang, H (2010), Experimental study on glacial lake outburst floods due to waves overtopping and erosion of Moraine dam. Annuals of Disas. Prev. Inst., Kyoto Univ., 53, 583-590.

Carey, M (2005), Living and dying with glaciers: people's historical vulnerability to avalanches and outburst floods in Peru. Global Planet. Change, 47, 122-124.

Carey, M (2008), Disasters, development, and glacial lake control in twentieth-century Peru. In: Wiegandt E (Ed.), Mountains: Sources of Water, Sources of Knowledge. Advances in Global Change Research, Springer, Netherlands.

Carey, M., Huggel, C., Bury, J., et al ( 2012), An Integrated Socio-environmental Framework for Glacier Hazard Management and Climate Change Adaptation: Lessons from Lake 513, Cordillera Blanca, Peru, Climatic Change, 3(3): 733-767.

Clague, J.J. and Evans, S (2000), A review of catastrophic drainage of moraine-dammed lakes in British Columbia. Quaternary Sci. Rev., 19, 1763-1783.

Gardelle, J., Arnaud, Y. and Berthier, E (2011), Contrasted evolution of glacial lakes along the Hindu Kush Himalaya mountain range between 1990 and 2009. Global Planet. Change, 75, 47-55.

Haeberli, W (2013), Mountain permafrost - research frontiers and a special long-term challenge. Cold Reg Sci Technol, 96, 71-76. doi:org/10.1016/j.coldregions.2013.02.004.

ICIMOD (2010), Glacial lakes and associated floods in the Hindu Kushi Hialayas [R]. ICIMOD Publications Unit, Kathmandu, Khumaltar, Lalitpur, Nepal.

Jiao, et al (2005), Variation of Zepu Glacier and Environmental Change in the Eastern Nyainqêntanglha Range since 3. 2 ka BP. Journal of Glaciology and Geocryology, 7(1): $74-79$ (in Chinese).

Liu, et al (2015), The contemporary glaciers in China based on the Second Chinese Glacier Inventory. Acta Geogrpahica Sinica, 70(1): 3-16 (in Chinese).

Mckillop, R.J. and Clague, J. (2007), Statistical, remote sensing-based approach for estimating the probability of catastrophic drainage from moraine-dammed lakes in southwestern British Columbia. Global Planet. Change, 56, 153-171.

Nadim, F. and Kjekstad, O (2009), Assessment of global high-risk landslide disaster hotspots. Landslides, 3(11), 213-221. 
Nat. Hazards Earth Syst. Sci. Discuss., doi:10.5194/nhess-2016-300, 2016

Manuscript under review for journal Nat. Hazards Earth Syst. Sci.

Published: 27 September 2016

(c) Author(s) 2016. CC-BY 3.0 License.
Natural Hazards

and Earth System

Sciences

Discussions

(c) $\underset{\mathrm{BY}}{(i)}$

425

426

427

428

429

430

431

432

433

434

435

436

437

438

439

440

441

442

443

444

445

446

447

448

449

Nayar, A (2009), When the ice melts. Nature, 461, 1042-1046.

Rachel, A.D. and Kelly, B.L (2001), Comparing the hurricane disaster risk of U.S. coastal counties. Nat. Haz. Rev., 2(3), 132-142.

Saaty, T.L (1977), A scaling method for priorities in hierarchical structures. J. Math. Psychol., 15, $234-281$.

Smith, K (2001), Environmental Hazards: Assessing Risk and Reducing Disaster, Routledge, London and New York.

Starmap Publishing House (2006), Atlas of China Traffic. Starmap Geographic Publishing House, Beijing. [In Chinese]

Wang, S.J. and Zhang, T (2013), Glacial lakes change and current status in the central Chinese Himalayas from 1990 to 2010. J. Appl. Remote Sens., 7(1) 073459. DOI: 10.1117/1.JRS.7.073459.

Wang, S.J., Qin, D.H., Xiao, C.D (2015), Moraine-dammed lake distribution and outburst flood risk in the Chinese Himalaya. Journal of Glaciology, 61(225): 115-126. doi: 10.3189/2015JoG14J097.

Wang, W.C., Yao, T.D., Gao, Y., et al (2011), A first-order method to identify potentially dangerous glacial lakes in a region of the southeastern Tibetan Plateau. Mt. Res. Dev., 31(2), 124-126.

Worni, R., Huggel, C. and Stoffel, M (2013), Glacial lakes in the Indian Himalayas - from an area-wide glacial lake inventory to on-site and modeling based risk assessment of critical glacial lakes. Sci. Total Environ., 468-469, S71-S84.

Worni, R., Stoffel, M., Huggel, C., et al (2012), Analysis and dynamic modeling of a moraine failure and glacial lake outburst flood at Ventisquero Negro, Patagonian Andes. J. Hydrol., 444/445, 134-145.

Wu, et al (2002), The Moraines of Xibu Glacier Area in the Nyainqentanglha Range. Acta Geoscientia Sinica, 23(4): 343-348 (in Chinese).

Yao, T.D (2010), Glacial fluctuations and its impacts on lakes in the southern Tibetan Plateau. Chin. Sci. Bull., 55(20), 2071. [in Chinese with English summary]

Zhao, et al (2006), Assessing the ecological security of the Tibetan plateau: methodology and a case study for Lhaze County. J. Environ. Manage., 80, 120-131. 